\title{
Wilhelm His, K. S. Geheimer Rath, Professor of Anatomy, Leipzig, Honorary Fellow of the Royal Society of Edinburgh, 1900-1904. By Professor D. J. Cunningham.
}

(Read July 4, 1904.)

Amongst the many remarkable men of science of a remarkable century Professor Wilhelm His will always be given a prominent and honoured place. In almost every branch of anatomy he has left his mark, and during the last thirty years no one has done so much to advance our knowledge of that subject.

Although a professor in Leipzig, where the best part of his work was accomplished, Germany was merely the country of his adoption. He belonged to an old Swiss family, and was born in Basel in 1831. It was there that His received his early education, and it was in the University of that town that he commenced, at the age of eighteen, the study of medicine. His career as a student was marked by a restless desire to profit by the tuition of the great teachers of that time, no matter where they were to be found. Thus in his second year of study we find him at Beme, where he came under the influence of Theile the anatomist and of Valentin the physiologist. In the following year (1850) he went to Berlin, where he had the singular good fortune to have as his teachers Johannes Müller and Robert Remak. There can be no doubt that this formed a crucial point in his career. He was profoundly impressed by the manner and method of the teaching of the great comparative anatomist Miuller, and it is believed that a lecture which he heard Remak deliver upon the development of glands first stimulated in him that curiosity in regard to development in general which in his after life led to such magnificent results. But his peripatetic pursuit of knowledge did not end in Berlin. In 1852 he went to Würtzburg. At that time Virchow was a young professor in this school, and His worked in his laboratory and conducted an investigation the results of which were subsequently published. Having completed lis studies, he graduated 
in Basel in 1854 ; and after spending some time in Prague, Vienna, and in the laboratories of Paris, and acting for a short period as a privat docent in his native town, he was called upon, at the age of twenty-six, to succeed Professor Meissner as Professor of Anatomy and Physiology in the University of Basel.

In Basel Professor His laboured for fifteen years, and by the work which he did he very early attracted the attention of those. engaged in similar pursuits. In 1872 the chair of Anatomy in Leipzig, which had been previously held by Weber, fell vacant, and Ludwig, the celebrated Leipzig physiologist; with conspicuous judgment and foresight, recognised in His the proper successor to Weber. There is good ground for the belief that it was mainly through the influence of Ludwig that His was translated to Leipzig.

Professor His displayed activity in so many departments of anatomy that it is an exceedingly difficult matter, within reasonable compass, to give anything like an adequate conception of the splendid work which he accomplished. There is no name that is more frequently on the lips of the teaching anatomist of the present day; there is no one who has exercised a more powerful influence in moulding anatomical thought in almost all branches of that subject. Still, there can be little doubt that it is his embryological work that will produce the most lasting impression. $U_{p}$ to the time when he entered this field of research very little was known regarding the special development of man. Human embryology in its earlier stages was represented in the book of anatomy by a very nearly blank page. What embryology was taught to the student of human anatomy was almost entirely derived from observations conducted on the embryos of the lower animals. Now, with the exception of the few days immediately succeeding the fertilisation of the ovum, we have a very nearly complete record of the development of man. This we owe to Professor His. Of course, all the work which has led to this result was not done by him alone-other workers have helped in certain departments; but His was the leading spirit. His not only laid the foundation, but with his own hands reared by far the greater part of the superstructure. His magnificent work, entitled Anatomie menschlicher Embryonen, and published in three parts, was completed in 1885 . 
This work is the mine from which anatomists of the present day have extracted the greater part of their knowledge of human development, and it is from it that they have borrowed the greater part of the embryological illustrations which are used in their text-books.

It is difficult to realise the labour and patience required to successfully carry out investigations into the development of man. Human embryos in the first month-and this is the important month-of development can only be obtained at rare intervals, and as often as not they come into the hands of the investigator in a condition unfit for proper research, and never in the condition in which the embryos of most of the lower animals can be secured. By the most assiduous search after specimens, and by the elaborate measures undertaken for their preservation, Professor His was enabled to overcome these initial difficulties.

But His did not content himself by publishing descriptions and drawings of the human embryo and its different organs: he likewise constructed models of the anatomy of the Enbryo at different stages of its growth. These models are singularly beautiful. The early human embryo is an exceedingly minute object; in the middle of the first month of development it measures little more than $2 \mathrm{~mm}$. in length. The skill which Professor His exhibited in the reconstruction and magnification of these small embryos was little short of marvellous. Wherever anatomy is taught these models form a part of the laboratory equipment, and they have proved of the greatest service, not only to the teacher and pupil, but also to all those engaged in embryological research.

If we might venture from so much material to select one result obtained by Professor His which at the present moment appears to possess a specially far-reaching significance, we would point to his investigations into the origin of nerve cells and the growth of nerve fibres. This research does not cover a great extent of ground, but even taken by itself it would be sufficient to establish the reputation of Professor His on a lasting and permanent basis. In the early brain and spinal cord the nerve cells assume shape and by a process of migration take up their several positions within the central nervous axis. At first there are no nervefibres, so the embryo at this stage has a brain and sninal nord hur 
these are not provided with nerves. The nerve-fibres grow out from the cells and pursue their several paths with the most unerring exactitude towards the elements with which they trtimately become connected. The fibres which form the efferent nerves grow out from the nerve-cells in the brain and cord; the fibres of the afferent nerves arise from the ganglion cells outside and grow into the brain and cord so as to establish their connections with the central nervous axis. 'This may seem a small point, and yet it forms the embryological basis of our modern conception of the manner in which the nervous system is built up, and also of the manner in which its different units or neurons are connected.

But it would be wrong, even in a short notice such as this of necessity is, to omit to refer to the useful work performed by Professor $\mathrm{His}$ in the department of topographical anatomy. During the last thirty or forty years our ideas in regard to the form and relations of the different parts of the human body have undergone a complete revolution. Professor His was one of the leading pioneers in bringing about this change.

It is not so long ago that the anatomist derived all his information in regard to the topography of the body from dissection alone. No other method was followed; and when, as in these times, it was not combined with measures for the preservation of the form of the parts under observation, the amount of information it yielded was limited, and not unfrequently misleading. Sections of the frozen body, introduced by Pirogoff, carried out to such perfection by Braune, and now practised by teachers all over the world, led to a great advance in every department of topographical work. It then became possible to check the results obtained by dissection, and correct many erroneous impressions for which the latter method was responsible.

The next step was taken by Professor His, who hardened the viscera in situ by prolonged injection of chromic salts; and it is no too much to say that the models which he prepared from these specimens, and which are at present used wherever the study of anatomy is pursued, have had a profound effect on anatomical thought and teaching. Recently the method of l'rofessor His has been brought to a state bordering on perfection by 
the introduction of formalin as the hardening reagent, and His was not slow to take advantage of this advance. One of his last papers, entitled Studien an gehärteten Leichen über Form und Lagerung des menschlichen Magens, deals with observations conducted in this manner, and was published as recently as last year.

The paper which Professor His wrote upon the skeleton of Johann Sebastian Bach, the distinguished musician, is of such general interest that I may be permitted to allude specially to it.

Bach, who died in 1750 , at the age of 65 , was buried in the churchyard of the Johanniskirche, but tradition alone pointed to. the site of the burial. In 1894, when the new church was in course of erection, it was very naturally considered desirable that the remains should be found, in order that they might be suitably reinterred. A search in the place indicated revealed an oaken coffin containing the skeleton of an aged man. By comparing the skull, which presented some peculiarities-more especially a marked projection of the lower jaw-with portraits of Bach, His was able to identify the skeleton as that of the famous musician, and he wrote an elaborate memoir on the remains. With much labour he was able to reconstruct from the skull the outline of the head, and he also devoted especial attention to the temporal bones, within which are encased the essential parts of the organ of hearing. There is an impression among certain anatomists who have given attention to the matter that the tympanic membrane of the ear in musicians is set in its bony frame more vertically than in ordinary mortals. His did not find this to be the case with Bach: the angle which the membrane formed with the floor of the auditory passage was $42^{\circ}$, whilst the average angle is said to be about $55^{\circ}$.

When His became head of the Anatomical Institute in Leipzig, Wilhelm Braune was appointed Professor of Topographical Anatomy in the same University. The association of these two. workers in different departments of the one subject was an extremely happy one. They suon became united by the ties of a warm friendship, and it is not surprising that, with a combination so strong, it was from the Leipzig school that the chief movement tcok place which led to so great a change in anatomical thought and method. 
It would hardly be possible to conceive two men so absolutely different both in temperament and in physical characters as the two Leipzig colleagues: Braune, big, bluff, hearty and almost boisterous in manner; His, tall, spare, and dark, with a sharp sallow face, keen black eyes, and a narrow but good forehead. He was diffident and restrained in manner, and it was only with those whom he knew well that he appeared at his best.*

No anatomist of our time has wielded so wide an influence within the limits of his own subject. - Students came to his laboratory from all parts of the Continent, from Great Britain, and from America. All who came with the right spirit were made heartily welcome and received every encouragement and help in their work. At the same time, Professor His possessed none of that grace and ease of expression which distinguishes his devoted friend and colleague, Professor Waldeyer of Berlin, none of the impressive Iucidity which is characteristic of the teaching of Sir William Turner. Still, he had those qualities which canght the attention and aroused the enthusiasm of his students, and great results followed. Many of his pupils, perhaps chiefly those in America, are now doing excellent work on their own account.

He died on the 1st of May last after a painful illness, borne with the most patient fortitude. To the last his mind was in his work. $\mathrm{He}$ was deeply interested in the Intemational Committee which had been appointed with the view of organising a combined effort in brain research. He was the chairman of this Committee, and had summoned by his own hand, in April, a meeting to be held in London on the 24th of May. Alas! he was not there to greet his colleagues.

* When Professor His visited Dublin in 1898 he was measured in the Anthropometrical Laboratory of the Anatomical Department. The following are the measurements which were obtained:-

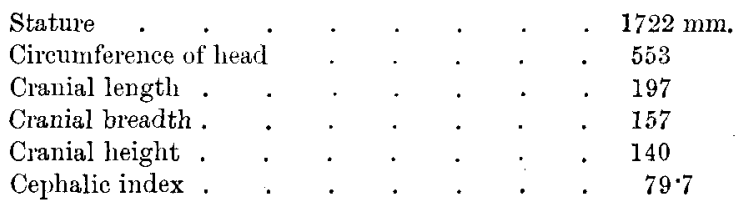

The average cranial height for adult males in Ireland is somewhere about $131 \cdot 3$, and for a group of thirty-six anatomists, measured at the same time as Professor His, 133.4 . 